\title{
Ethnoecology Majegan (Tegalan) Local Communities on the Slopes of Mount Slamet, Paguyangan District, Brebes Regency, Central Java
}

\author{
Nabela Fikriyya $^{1 *}$, Nisyawati ${ }^{1}$, M. Silalahi ${ }^{2}$, H. Helmanto ${ }^{1}$, R.N. Zulkarnaen ${ }^{1}$
}

\author{
${ }^{1}$ Biology Department, Faculty of Mathematics and Science, Universitas Indonesia, Jakarta, Indonesia \\ ${ }^{2}$ Departement of Biology Education, Faculty of Education and Teacher, Training, Universitas Kristen Indonesia \\ *Corresponding author. Email: nabela.fikriyya@ui.ac.id
}

\begin{abstract}
Indonesian communities have variety of local knowledge in managing natural resource that are formed form heredity. The threat of modernization that is not approporite with local culture causes degradation of local knowledge, including the Jawa ethnic community on the slopes of Mount Slamet. The purpose of this study is to document the local knowledge of the slopes Mount Slamet Community in utilizing majegan (tegalan or kebon) unit landscape. The study was carried out in 3 villages namely, Ragatunjung, Cipetung and Pandansari, Paguyangan District. The method used is a semi-structured interview, observation and literature study. The number of key informants in this study is 8 people and respondents were 30 people. The result showed that the community of slopes of Mount Slamet recognize and utilize majegan (tegalan or kebon) as dry land that used to grow annual vegetable crops and perennial plant that are located separately from the house yard and its use is not moving. Majegan (tegalan or kebon) managed by tumpangsari (intercropped) and only relies on rains water. Some type of trees found around majegan (tegalan or kebon), is jackfruit (Artocarpus heterophyllus), cloves (Syzygium aromaticum), waru (Hibiscus tiliaceus) etc. and annual vegetable crops found include, kol (Brassica juncea), budin (Manihot esculenta), cayenne pepper (Capsicum annuum), corn (Zea mays), potatoes (Solanum tuberosum) etc.
\end{abstract}

Keywords: Ethnoecology, Majegan, Paguyangan community, Slamet Mountain slope community.

\section{INTRODUCTION}

Indonesia is an agrarian country because the majority of the population has a livelihood in agriculture. Dry land agriculture is one of the agricultural systems used by Indonesia community. This is supported by the dry land area which reaches $75 \%$ (143 million ha) of the total land area of Indonesia namely, 189.1 million ha, while the area of wetlands is only 46.1 million ha [1]. The practice of dry land farming cannot be separated from the knowledge of the community in managing natural resources. The system has been developed by Indonesian community for a long time and has become part of sustainable land management [2]. Each community has different knowledge in managing dry land agriculture. The majority of Jawa community refer to dry land agriculture as kebon or tegalan. Generally there are several terms used by the community in referring to dry land agriculture or gardens such as, kebon talun (rural communities in West Java), kaleka (Kapuas Dayak Tribe, Central Kalimantan), munan (Dayak Tunjung Tribe), sinpunkng (Benuang Dayak Tribe) and Lembo (Kutai) [3].
One of the communities applying the dry land farming system is the Jawa community on the western slope of Mount Slamet in Paguyangan district. Community settlements in the area around the slopes of Mount Slamet can be found to an altitude of $1800 \mathrm{~m} \mathrm{dpl}$. The majority of the people on the slopes of Mount Slamet work as farmers and call dry land in terms of majegan or tegalan or kebon. Majegan (tegalan or kebon) consists of various types of plants which are planted in a mixture of parenial tree plants and annual vegetable crops.

Land limitations, population growth, economic needs, and the emphasis on the conversion of land into monoculture agriculture are some of the problems faced by the Paguyangan community related land use and management. These problems have pushed the Paguyangan community to have knowledge related to land management and the utilization of natural resources which were passed on orally. However, the threat of modernization that is not appropriate to the local culture has caused a shift in the local knowledge base that leads to the degradation of local knowledge [4]. In addition, scientific documentation of local knowledge on the slopes of Mount Slamet has never been done. According to Thamrin[5], can lead to fears of the extinction of local knowledge. 
The concept of landscape utilization owned by the local community needs to be preserved because it is one of the traditional conservation efforts (Suhartini 2009) [6]. In addition, various studies on the relationship between local communities and natural resource management show that local knowledge can reduce the impact of damage and sustain the environment (Helida 2016) [7]. Documentation of local knowledge and resource management can be studied through ethnoecology. Ethnoecological approaches emerge as a bridge between natural science and social science in managing the environment in a sustainable manner (Hilmanto 2010) [8]. The purpose of this study is to document the knowledge of the slopes of Mount Slamet community in utilizing the majegan (tegalan or kebon).

\section{MATERIALS AND METHODS}

The study was conducted in June-July 2019 in 3 villages on the slopes of Mount Slamet namely, Pandasari, Ragatujang, and Cipetung, Paguyangan District, Brebes Regency. Data processing and analysis was carried out at the Department of Biology FMIPA UI.

The material used is interview guidelines, observation guidelines, and questionnaire sheets. Data collection was carried out in 4 steps, firstly in-depth interviews with key informants. Key informants were selected purposively including village officials and community leaders with a total of 8 people. Second, the survey method through interviews with respondents. Respondents were determined purposively with 30 key informants. Respondents are people who work as farmers or farm laborers. Third, recording and documentation during field observations. Fourth is the study of literature.

Data analysis was performed by cross-checking, summarizing and synthesizing from various data sources, such as observation, in-depth interviews with informants, and secondary data such as village statistics [9].

\section{RESULT AND DISCUSSION}

Table 1. Conditions of research locations in the villages of Ragatunjung, Cipetung and Pandansari

\begin{tabular}{|c|c|c|c|c|}
\hline No & Lecaticens (village) & Ragatumingiz & Cipstiule & Pandausan \\
\hline 1. & Laige & $1216 \mathrm{ha}$ & $236 \mathrm{ha}$ & Sont ta \\
\hline 2 & Ixvatim & $800 \mathrm{~m}$ & $1112 \pi$ & $1451=$ \\
\hline 3. & Lane of mitiogin & E6he & S1 lia & 476 be \\
\hline \multirow[t]{5}{*}{4.} & Bardertine & & & \\
\hline & Nonth (vilase) & Wanatos & Cillaw & Wharas \\
\hline & Soth (ovllage) & Ragratinyuay & Waniricta mid Kretek & Wuatita \\
\hline & Fanc (vilups) & Findancan & Cypstany & Karmaptenyah \\
\hline & West (valiage) & Cistour & $\begin{array}{l}\text { Negarvidun } \\
\text { Satucrame }\end{array}$ & Cipstume \\
\hline 5 & Toeal pergidation & $2006 \mathrm{progle}$ & 10.548 pergie & 10.105 propgie \\
\hline 6. & Toal of framily hents & 580 & 2591 & 3249 \\
\hline
\end{tabular}

The research location in Ragatunjung (800 m), Cipetung $(1.112 \mathrm{~m})$ and Pandansari $(1.400-1.800 \mathrm{~m})$ (Kodirin 2018) (Table 1). The majority of the community on the slopes of Mount Slamet have livelihood in agriculture. The majority of the community are farm laborers, only $32,15 \%$ male farmers and 1,61\% female farmers in Cipetung and 19,94\% Ragatunjung male farmers and $11,40 \%$ female ragatunjung farmers. Incontrast to Pandansari, where all of them are farm laborers (Figure 1).



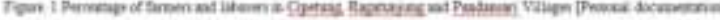
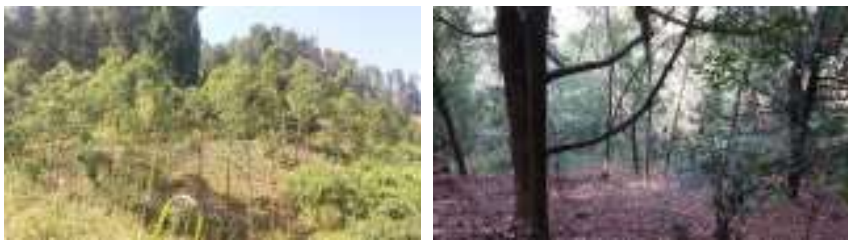

Figure 2. The condition of majegan (tegalan) in the slopes of Mount Slamet Paguyangan [personal documentation].

Majegan (tegalan or kebon) is a dry agricultural land used by the community to grow horticultural crops (annual vegetables) combined with parenial tree crops. Majegan (tegalan or kebon) area is located separately from the yard around the house and its use does not move (Figure 2.). Majegan land is cultivated by wanatani or agroforestry. The cultivation process starts with land damel (land management), making beds (Figure 3.a), installing plastic mulch (Figure 3.b), planting and fertilizing and finally watering. Majegan land is cultivated by wanatani or agroforestry. The cultivation process starts with damel lahan (land management), making bedengan (raised beds) (Figure 3.a), installing plastic mulsa (mulch) (Figure 3.b), planting and fertilizing and the last is watering.

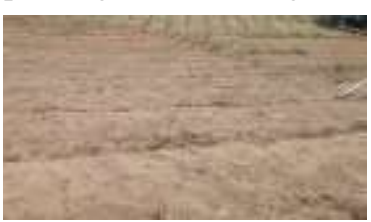

(a)

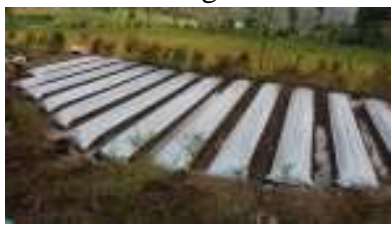

(b)
Figure 3. (a) The process of cultivating land and making bedengan (b) the process of applying mulsa to bedengan

The variation of tree species found in majegan can be seen in table 2 and the types of vegetables that are cultivated by the community can be seen in table 3 . Cloves and kaliptus are some of the trees planted by high-value communities. Slamet Mountain slope area in Paguyangan is the center of the second potato producer. 
Table 2. Types of parenial tree plants in Ragatunjung, Cipetung and Pandansari Villages

\begin{tabular}{|l|l|l|}
\hline No & $\begin{array}{l}\text { Local } \\
\text { name }\end{array}$ & \multicolumn{1}{|c|}{ Scientific name } \\
\hline 1 & Kaliptus & Eucalyptys sp \\
\hline 2 & Surya & Toona sinensis \\
\hline 3 & Ginitri & Elaeocarpus sphaericus \\
\hline 4 & Besiar & Paraserianthes falcataria \\
\hline 5 & Puspa & Schima wallichi \\
\hline 6 & Kelor & Moringa oleifera \\
\hline 7 & Kaliandra & Calliandra calothyrsus \\
\hline 8 & Cengkeh & Syzygium aromaticum \\
\hline 9 & Kelapa & Cocos nucifera \\
\hline 10 & Alpukat & Persea Americana \\
\hline 11 & Pete & Parkia speciose \\
\hline 12 & Jambu krukut & Psidium guajava \\
\hline 13 & Cecek & Artocarpus heterophyllus \\
\hline 14 & Pelem & Mangifera indica \\
\hline 15 & Jambu air & Syzygium aqueum \\
\hline 16 & Damaran & Agathis dammara \\
\hline 17 & Mahoni & Swietnia macrophylla \\
\hline 18 & Akasia & Acacia auriculiformis \\
\hline
\end{tabular}

Table 3. Types of annual vegetable crops in Ragatunjung, Cipetung and Pandansari Villages

\begin{tabular}{|r|l|l|}
\hline \multicolumn{1}{|l|}{ o } & \multicolumn{1}{|c|}{ Nocal } & \multicolumn{1}{c|}{ Scientific name } \\
\hline 1 & The & Thea sinensis \\
\hline 2 & Jagung & Zea mays \\
\hline 3 & Bodin & Manihot esculenta \\
\hline 4 & Gedhang & Musa paradisiaca \\
\hline 5 & Cabe & Capsicum Annum \\
\hline 6 & Selebor & Brassica sp \\
\hline 7 & Kunir & Curcuma domestica \\
\hline 8 & Tales & Colocasia esculenta \\
\hline 9 & Gandul & Carica papaya \\
\hline 10 & Cabe rawit & Capsicum frustescens \\
\hline 11 & Kol & Brassica juncea \\
\hline 12 & Terong & Solanum melongena \\
\hline 13 & Ganyong & Canna edulis \\
\hline 14 & Nanas & Ananas comosus \\
\hline 15 & Kapulaga & Amomum cardomomum \\
\hline 16 & Wortel & Daucus carota \\
\hline 17 & Kentang & Solanum tuberosum \\
\hline 18 & Waluh & Sechium edule \\
\hline 19 & Mencang & Allium fistulosum \\
\hline 20 & Kacang jubleg & Vigna angularis \\
\hline 21 & Buncis & Phaseolus vulgaris. \\
\hline
\end{tabular}

1. Characteristics of Respondents and Villages
Paguyangan District is one of the areas on the slopes of Mount Slamet which is located at the southern end of Brebes Regency dan is directly adjacent to the Banyumas residency [10]. The location of Mount Slamet is in the western part of Central Java, namely on the border between Pemalang, Banyumas, Purbalingga, Tegal and Brebes regencies [11,12]. Community settlements in the area around the slopes of Mount Slamet can be found to an altitude of $1800 \mathrm{~m}$. Paguyangan District consists of 12 villages, five of which are located in the highlands and the other in the lowlands [13]. Three of the five villages in the highlands are Ragatunjung $(800 \mathrm{~m})$, Cipetung $(1.112 \mathrm{~m})$ and Pandansari (1400-1800 m).

Access road to the slopes of Mount Slamet can be reached by land, but only by private vehicles because public transportation does not reach the area. The terrain that must be taken is quite difficult because to the uphill and slightly rocky road conditions. This causes the majority of people to have motorized vehicles to facilitate access to the city or carry out their daily activities. Health and education facilities in the three villages are quite adequate. Educational facilities available in each village are different, for example in Cipetung only up to elementary level, Ragatunjung and Pandansari Village up to Junior High School level [14]. The majority of the community continues their schooling to next village or go to the city. Health facilities are only owned by Pandansari namely, Puskesmas pembantu (supporting health centers). This is very helpful for local residents, because Pandansari is the farthest area from the city area.

The majority of community in Ragatunjung, Cipetung and Pandansari are Jawa (Javanese) and are Muslim. Jawa community often call themselves Wong Jawa or Tiang Jawi. The unity of Jawa community life is led by the lurah or village head. Each village consists of several parts called dukuh or dusun (kampung) and each of dusun is leads by a dusuh head. Jawa tribe are the most widely population than other tribes and have the most extensive distribution [15]. Jawa community are people who live in Javanese cultural traditions [16]. The Javanese cultural region covers the middle to the eastern part of Jawa Island, including the areas around Banyumas, Kedu, Madiun, Malang, Yogyakarta and Surakarta. In addition to inhabiting the original indigenous territories on the islands of Central and East Java, the Javanese are also spread as trasmigrants in various regions in Indonesia [15].

Jawa community on the slopes of Mount Slamet use Javanese language which is included in the western part of Javanese dialect, Tegal. The suffix in communication use the suffix "a", not "o". Javanese is included in the Austronesian language family, the western MalayPolynesian group that has socially specific levels of language. Javanese language in general has three levels, namely Jawa ngoko (rough), Jawa madya, and Jawa krama inggil or alus (smooth). Each level of language has a different usage. The majority of Jawa commuity on the slopes of Mount Slamet, Paguyangan district still apply the use of the three language levels. Jawa ngoko is used for people who are already known to be close, to younger people and lower social degrees and Jawa krama inggil is used for people who are not yet close, older and higher 
social degrees. Jawa madya language arises from variations in the use of ngoko and Jawa inggil [15].

Farming is the livelihood of the majority of Jawa community who are located in the villages. Not all farmers have private land, there are farmers who become farm laborers by cultivating land owned by other people or land owned by Perhutani. The majority of the community are farm laborers, only $32,15 \%$ male farmers and $1,61 \%$ female farmers in Cipetung and 19,94\% Ragatunjung male farmers and $11,40 \%$ female ragatunjung farmers. Incontrast to Pandansari, where all of them are farm laborers (Figure 1). Besides farming, the majority of community also have livestock in the form of cows and goats. Maintain goats, cows and and poultry is more preferable and widely practiced by the Jawa community, because it does not require large tracts of land [17]. Of the three villages above, only Ragatunjung has paddy fields. Cipetung is the smallest village and the smallest population than others. The area of Cipetung is $28,1 \mathrm{~km} 2$ with a population of 2.006 people. The population of Pandansari Village is 10.105 people and Ragatnjung Village is 10.558 people (Table 1 ).

The culture of gotong royong (mutual cooperation) is still maintained by Jawa community on the Slamet Mountain Slope to maintain the kinship. This can be reflected through community service activities in road construction, house repairs or weddings and khitanan (circumcisions). Communities carry out these activities voluntarily, without pay. Community involvement in social activities that have been carried out from generation to generation makes bond ties close. Mutual cooperation is also reflected in the role of women in the management of agricultural land. The women on the slopes of Mount Slamet in Paguyangan District have a separate working group of three to five people working on land or participating with their husbands. Both workloads are almost the same. the women also took grass for livestock. The difference lies only in working hours, the majority of women are only until 13:00 until 17:00, but men can until the evening until 22:00 or even stay if the watering season comes. Some women also become casual daily laborers or temporary workers, only working during the harvest season.

\section{Characteristics and management of majegan (tegalan or kebon)}

The majority of the slopes of Mount Slamet in Paguyangan District are familiar with eight types of landscape lunit, among others, karangan or pekarangan (yards), majegan or tegalan or kebon (dry fields), sabin (rice fields), wanah or kontrakan (production forests), protected forest planning areas (RHL), tanah bengkok (land owned by villeges), Telaga Ranjeng Nature Reserve and tea plantations. However, based on the characteristics of each village, not all communities utilize all types of landscapes. The majority of the types landscape units utilized by the community are majegan tegalan or kebon (dry fields) and wanah or kontrakan (production forests). Rice fields are only owned by Ragatunjung and the protected forest plan area (RHL) is only utilized by Pandansari community. Ragatunjung also has a protected forest plan area (RHL) but has not been used for a long time. Ragatunjung community call it kubang buyut because in the area there is a pool which is a reservoir of water from a spring that is above the protected forest plan area (RHL).

Jawa community on the slopes of Mount Slamet classify landscape units in addition to functions and characteristics, the community also groups by ownership. Majegan Majegan (tegalan or kebon) landscape unit is one private or family owned land which is majority owned and utilized by communities in Ragatunjung, Cipetung and Pandansari. The area of majegan (dry fields) of each village is 66 ha 51 ha and 476 ha. The origin of the word majegan is tax or pajeg in Javanese. Named majegan because the land is taxable land by the government because it is privately owned land, unlike wana or kontakan land which is a forest area owned by Perhutani. Majegan is also known by another name, namely tegalan and kebon. Majegan (tegalan or kebon) is a dry agricultural land used by the community to grow horticultural crops (annual vegetables) combined with parenial tree crops. Majegan (tegalan or kebon) area is located separately from the yard around the house and its use does not move (Figure 2.).

Dry land is one form of agricultural landscape that is commonly scattered in upper watersheds (DAS). Mount Slamet is one of the Serayu watersheds. Majegan (tegalan or kebon) management on the slopes of Mount Slamet is generally managed by wanatani or agroforestry. Agroforestry is an integrated land use system, which has social and ecological aspects. Agroforestry practices are carried out by combining trees with agricultural crops, pastures or livestock, or both together and in rotation, so that from one unit of land an optimal total vegetable or animal yield is achieved [18,19]. The purpose of agroforestry is to minimize the risk of failure and achieve optimal land production and use [20].

The agroforestry system in Indonesia has actually been applied for a long time, for example in the form of mixed gardens, yard systems, kebon talun [20], tegalan trees, fields (ladang), fallow land (shrubs), and community plantations [21]. Traditional agroforestry practices generally develop based on the experience of communities or farmers hereditary from their ancestors [20]. Agroforestry is widely adopted by farmers in Indonesia because it is a land use technique that is suitable to be done on narrow land (yards) and tegalan (dry land) [22]. The results obtained can be sustainable, namely short-term products in the form of non-timber products and wood products as long-term results [21].

Agroforestry systems implemented by the slopes of Mount Slamet are included in simple agroforestry that is managed tumpangsari (intercropping). Since the Dutch era the intercropping system has been implemented by a forestry company to manage teak forests in Jawa. The initial purpose of using the intercropping (tumpangsari) system was to reduce the cost of planting, but in development it was more aimed at supporting efforts to improve the welfare of communities around the forest [20]. Intercropping has several advantages, among others, reducing the risk of crop failure, increasing overall production, efficient use of land, water and sunlight as natural resources, preserving soil fertility can be maintained because of the presence of plants throughout the year, controlling weeds and improving the nutrition of farming families who obtained from various plants [23]. 
Some Javanese community on the slopes of Mount Slamet still apply fallow periods (left) in land management or called garung. Fallow or garung is a period of stopping or resting when the land cannot provide support for the cultivation of annual crops. One of the main factors causing the fallow situation is the dry season, so water stress makes a limiting factor for the growth of annual crops [24]. According to farmers on the slopes of Mount Slamet, Paguyangan district, by leaving the land for about five months during the dry season, the soil is more fertile and the crops are better when harvested. One way for the community to deal with the garung period is to manage the land called damel lahan which purpose to prepare for the next planting period.

Damel lahan comes from Javanese language which means to make land. Making land (damel lahan) is done by hoeing it. Land management is carried out aiming that the soil becomes loose, so that nutrients and water are optimally absorbed by plant roots. The tree planting pattern in majegan (tegalan or kebon) is planted by circling the land, or randomly or lined up. Trees are planted with irregular spacing either on the land or on the boundaries of land ownership. The pattern of planting annual vegetable crops is carried out on majegan (tegalan or kebon) fields in bedengan (Figure 3a). Bedengan or guludan are mounds deliberately made by farmers to grow vegetables of a certain width and height and between the two bedengan separated by drains or drainage ditches. Drains are useful for draining water so that soil aeration or soil moisture in bedengan is maintained. Bedengan (raised beds) are made to make planting, maintenance and harvest easier [25]. Making beds is done after the land damel process. Beds are made with a width of approximately $60-75 \mathrm{~cm}$ and a height of $10-20 \mathrm{~cm}$.

The next step is the installation of plastic mulsa (mulch) perforated with a certain spacing depending on the plant to be planted (Figure 3b). The use of mulsa (mulch) is one way for Jawa community on the slopes of Mount Slamet to minimize erosion. The slope area of Mount Slamet in Paguyangan which has high rainfall is $8207 \mathrm{~mm} /$ year [14]. According to Wahyunto and Shofiyati[26], high rainfall caused the washing of most cations or nutrients which were quite intensive, so that many nutrients were lost because erosion. The use of plastic mulsa (mulch) is useful to protect the soil from rainwater so as to reduce erosion and maintain soil moisture in the dry season while increasing soil organic matter content $[27,28]$. Oktaviani and Batoro [29], emphasized that the provision of plastic mulsa (mulch) serves to reduce the competition of cultivated plants with wild undergrowth.

Planting is carried out after processing the soil and making plant holes. Plant holes are determined depending on the type of plant. Spacing and hole depth must be considered, according to the community each plant type is different depending on the type of root and height of the plant in the adult phase. Fruit and wood producing plants are planted at a depth of $25 \mathrm{~cm}$ layer and vegetable plants are planted at a depth of $3 \mathrm{~cm}$. This is in line with the statement Hilamnto[17] the most fertile land only reached $25 \mathrm{~cm}$.

The next step is the process of watering which aims to meet the needs of water and plant roots can function properly, namely absorbing water and nutrients optimally. The absorption of water and nutrients is useful for plant growth and crop yields. Majegan (tegalan or kebon) owned by the Javanese people on the slopes of Mount Slamet is a dry land with water needs that are entirely depend on rainwater, so that during the dry season the majority apply fallow on their land. The principle of giving water to dry land agriculture, especially seasonal food crops, is the use of water that is efficient and effective and provides maximum results [30].

In contrast to the majority of Pandansari Village people who apply watering by means of sprinkler irrigation namely, the provision of water to plants made from the plants in the form of dispersal using a water pump. The working principle of the sprinkler is to put pressure on the water in the pipe and emit it into the air so that it resembles rain [31]. The watering includes overhead irrigation because water is given or flushed from above like rainwater [30]. The watering portion between plants has a different time period. Sprinklers must be moved on time so that water that falls on the surface of the ground is not excessive. The majority of vegetable crops are carried out twice a day in the dry season with a time of approximately 2 hours per land.

\section{Types of plants in the Majegan (tegalan or kebon)}

Agroforestry is a form of local knowledge possessed by the Jawa community on the slopes of Mount Slamet in response to land limitations and climate change. The slope area of Mount Slamet in Paguyangan has an average temperature of $16-200 \mathrm{C}$ and a rainfall of $8207 \mathrm{~mm} /$ year [18]. Dry land with high rainfall (> $2000 \mathrm{~mm} /$ year) and quite long according to Wahyunto and Shofiyati [26], including drylands with wet climate. According to Sardjono[32], mountainous regions with cooler and wetter climates are ideal areas for growing vegetables and fruits. This is related to the availability of sufficient water and the opportunity for a fairly long planting period, $8-12$ months [26].

The types of trees planted on the slopes of Mount Slamet in Paguyangan are very diverse both those with high economic value or less high value (Table 2). High economic value trees found on the slopes of Mount Slamet include, among others, kaliptus (Eucalyptys sp), cengkeh (Syzygium aromaticum), mahoni (Swietnia macrophylla) etc. In addition, also found trees of lower economic value such as waru (Hibiscus tiliaceus) and akasia (Acacia auriculiformis) trees which are used for firewood and kalliandra (Calliandra calothyrsus) which are used for fodder. One of the trees cultivated by the majority of the people of Ragatunjung Village is cengkeh (Syzygium aromaticum). The main product of the clove plant is the clove flower which is usually served in dry form [26]. Cengkeh (Syzygium aromaticum) is one type of spice that has many benefits, one of which is used in the basic ingredients of medicines. In contrast to Cipetung Village, the majority of which were found were kaliptus trees which were used for building materials by the community. Besides being used as building material, the kaliptus can also be used as raw material for making paper. The cutting down of the calypus tree is around $7-8$ years [34].

Ragatunjung has a higher variation and proportion of tree plants, 12 of 18 species of plants were found (Table 2). This was influenced by the characteristics of the majegan 
(tegalan or kebon) area being the steepest and rugged land (Figure 1b). Dariah et al [35] emphasized that the importance of regulating the proportion of annual and annual crops on dry land, the steeper the slope should be the higher the proportion of parenial tree crops. In contrast to Pandansari Village, fewer tree species were found and the majority were used for vegetable crops.

The Javanese community on the slopes of Mount Slamet in Paguyangan is an area of annual superior vegetable commodities [34]. The slope area of Mount Slamet is the second center for producing potatoes (Solanum tuberosum) after Sirampog District. Planting annual vegetable crops almost all year round by intercropping is one of the vegetative conservation techniques applied by the community. According to Haryati [27], planting vegetables throughout the year, especially in the rainy season can reduce erosion and in the dry season can reduce evaporation because agricultural land is closed throughout the year. Planting patterns carried out by farmers are very diverse with very high variations. In addition to the community planting vegetables and trees, majegan (tegalan or kebon) areas are also planted with naprer grass (Pennisetum purpureum) which is used for animal feed. According to Bokings (2013), planting naprer grass (Pennisetum purpureum) can affect the stability of slopes so as to minimize erosion damage.

\section{CONCLUSION}

Based on the research it can be concluded that the communities in Cipetung, Ragatunjung and Pandansari utilize the landscape units of mejegan or tegalan or kebon as dry agricultural land. The land is managed by agroforestry or simple agroforestry with a tumpangsari (intercropping) system, which is planting trees with one or more annual crops. The majority of tree species cultivated are high economic value plants such as cloves (Syzygium aromaticum) and fruit-producing plants such as mango (Mangivera indica) and jackfruit (Artocarpus heterophyllus). In addition, the area also has the potential to produce various types of vegetables and crops. One of them is as the second center for producing potatoes (Solanum tuberosum) in Brebes Regency. Another potential is the animal husbandry sector that still needs to be developed and gets the attention of the local government.

\section{ACKNOWLEDGMENT}

The author would like to thank as much as possible the Village Head and the residents of the Villages of Cipetung, Pandansari and Ragatunjung, Paguyangan District, Brebes Regency, Central Java, who participated in this study. Thank to Department of Biology, Faculty of Mathematics and Natural Sciences, Universita Indonesian for their guidance and direction. And to all parties involved and assisted in this research. The research was funded by the Hibah Publikasi Internastional Terindeks untuk Tugas Akhir Mahasiswa
(PITTA) No: NKB-0651 / UN2.R3.1 / HKP.05.00 / 2019.

\section{REFERENCES}

[1] Mulyani, A \& M. Sarwani. 2013. Karakteristik dan potensi lahan sub optimal untuk pengembangan pertanian di Indonesia. Jurnal Sumberdaya Lahan 7(1): $47-55$.

[2] Rahu, A.A, K. Hidayat, M. Ariyadi, \& L. Hakim. Management of Kaleka (traditional gardens) in Dayak community in Kapuas, Central Kalimantan.

International Journal of Science and Research 3(3): $205-210$

[3] Hakim, L. 2014. Etnobotani dan manajemen kebun-pekarangan rumah: ketahanan pangan, kesehatan dan agrowisata. Selaras, Malang: viii +280 hlm.

[4] Prettya, J., B. Adamsb, F. Berkesc, S.F de Athayded, N. Dudleye, E. Hunnf, L. Maffig, K. Miltonh, D. Rapporte, P. Robbinsi, E. Sterlingj, S. Stoltonk, A. Tsingl, E. Vintinnerk \& S. Pilgrimm. 2009. The intersections of biological diversity and cultural diversity: Towards integration. Conservation and Society 7(2): $100-112$.

[5] Thamrin, H. 2013. Kearifan lokal dalam pelestarian lingkungan (the lokal wisdom in enviromental sustainable). Kutubkhanah 16(1): 46-59.

[6] Suhartini, S. 2009. Kajian kearifan lokal masyarakat dalam pengelolaan Sumberdaya alam dan lingkungan. Prosiding Seminar Nasional Penelitian, Pendidikan dan Penerapan MIPA. 206-218.

[7] Helida, A., E.A.M. Zuhud, H. Hardjanto, Y. Purwanto \& A. Hikmat. 2015. The Ethnography of Kerinci. Komunitas 7(2): 283-296.

[8] Hilmanto, R. 2010. Etnoekologi. Universitas Lampung, Bandar Lampung: viii + 115 hlm.

[9] Newing, H., C.M Eagle, R.K Puri, \& C.W Watson. 2011. Conducting Research in Conservation: Social Science Methods and Practice. Routledge, London: xxii +376 hlm.

[10] BPS. 2018. Kabupaten Brebes dalam Angka 2018. Badan Pusat Statistik Kabupaten Brebes, Brebes: $\mathrm{xxx}+279 \mathrm{hlm}$.

[11] Pratomo, I. \& M. Hendrasto. 2012. Ekologi Gunung Slamet: Karakteristik erupsi Gunung Slamet, Jawa Tengah. LIPI Press, Jakarta: xiv + 261 hlm. 
[12] Widodo, P. \& D.N. Wibowo. 2012. Ekologi Gunung Slamet: Araceae di Lereng Selatan Gunung Slamet. LIPI Press, Jakarta: xiv + 261 hlm.

[13] Kodirin, K. 2016. Statistik daerah Kecamatan Paguyangan. Badan pusat statistik Kabupaten Brebes, Brebes: iv $+22 \mathrm{hlm}$.

[14] Kodirin, K. 2018. Kecamatan Paguyangan dalam Angka 2018. Badan Pusat Statistik Kabupaten, Brebes: xiv +70 hlm.

[15] Hidayah, Z. 2015. Ensiklopedi: suku bangsa di Indonesia. Yayasan Pustaka Obor Indonesia, Yogyakarta: xxii + 270 hlm.

[16] Siswanto, D. 2010. Pengaruh pandangan hidup masyarakat Jawa terhadap model kepemimpinan (tinjauan filsafat sosial). Jurnal Filsafat 20(3): 198_216.

[17] Hilmanto, R. 2009. Sistem local ecological knowledge dan teknologi masyarakat lokal pada agroforestry. Universitas Lampung, Bandar Lampung: viii +105 hlm.

[18] Nair, P.K.R. 1987. An Introduction to Agroforestry. Kluwer Academic Publishers, London: xv +499 .

[19] Huxley, P. 1999. Tropical Agroforestry. Blackwell Science Ltd, United Kingdom: xiii + 371 hlm.

[20] Wulandari, C. 2011. Agroforestry: Kesejahteraan masyarakat dan konservasi sumberdaya alam.

Universitas Lampung, Bandar Lampung: ix + 78 hlm.

[21] Hadi, E.E.W., S.M Widyastuti, \& S. Wahyuono. 2016. Keanekaragaman dan pemanfaatan tumbuhan bawah pada sistem agroforestri di Perbukitan Menoreh, Kabupaten Kulonprogo. (Diversity and untilization of understorey in agroforestry system of Menoreh Hill, Kulonprogo Regency). Jurnal Manusia dan Lingkungan 23(2): 206-215.

[22] Kusumedi, P \& N.A Jariyah. 2010. Analisis Finansial Pengelolaan Agroforestri Dengan Pola Sengon Kapulaga di Desa Tirip, Kecamatan Wadaslintang, Kabupaten Wonosobo. Jurnal Penelitian Sosial dan Ekonomi Kehutanan 7(2): 93-100.

[23] Minardi, M. 2009. Optimalisasi pengelolaan lahan kering untuk pengembangan pertanian tanaman pangan. [Pidato Pengukuhan Guru Besar Ilmu Tanah], Universitas Sebelas Maret, Surakarta: $41 \mathrm{hlm}$.

[24] Suryanto, P., W.B Aryono, \& M.S Sabarnurdin. 2006. Model bera dalam sistem agroforestry (fallow land model in agroforestry systems). Jurnal manajemen hutan tropika 12(2): $15-26$.

[25] Kurnia, U. 2004. Prospek pengairan pertanian tanaman semusim lahan kering. Jurnal Litbang Pertanian 23(4): 130-138.

[26] Wahyunto, W. \& R. Shofiyati. 2014. Wilayah Potensial Lahan Kering untuk Mendukung Pemenuhan Kebutuhan Pangan di Indonesia. Pusat Penelitian dan Pengembangan Tanaman Pangan, Bogor: 315 hlm.

[27] Haryati, U., T. Budiarti, \& A.D. Makalew. 2013 Konservasi lansekap pertanian lahan kering berbasis sayuran mendukung pengembangan agrowisata di dataran tinggi Merbabu. Prosiding Seminar Nasional Peningkatan Produktivitas Sayuran Dataran Tinggi $60-87$.

[28] Sutono, S. 2014. Mengelola lahan kering terdegradasi menjadi lahan pertanian lebih produktif. IAARD Press Badan Penelitian dan Pengembangan Pertanian, Jakarta: viii +77 hlm.

[29] Oktaviani, R. \& J. Batoro. 2017. Etnoekologi tanaman budidaya di bawah naungan pinus (pinus merkusii Jungh. \& de Vriese) di Desa Duwet Kedampul, Kecamatan Tumpang, Kabupaten Malang. Biotropika 5(1): 8-13.

[30] Kurnia, U., H. Suganda, D. Erfandi, \& H. Kus nadi. 2004. Teknologi Konservasi Tanah pada Lahan Kering Berlereng: Teknologi konservasi tnah pada buidaya saturan dataran tinggi. Pusat Penelitian dan Pengembangan Tanah dan Agroklimat Badan Penelitian dan Pengembangssssan Pertanian Departemen Pertanian, Bogor: ix +216 hlm

[31] Sudjarwadi, S. 1987. Dasar-dasar teknik irigasi Keluarga Besar Teknik Universitas Gadjah Mada, Yogyakarta: iv + $92 \mathrm{hlm}$.

[32] Sardjono, M.A., Djogo, T., Arifin, H.S., \& Wijayanto, H. 2003. Klasifikasi dan pola kombinasi komponen agroforestri. Indonesia World Agroforestry Centre (icraf) Southeast Asia, Bogor: xi +25 hlm.

[33] Nurdjannah, N. 2004. Diversifikasi Penggunaan Cengkeh. Perpektif 3(2): 61-70.

[34] Mindawati, M. A. Indrawan, I. Mansur \& O. Rusdiana. 2010. Analisis sifat-sifat tanah di bawah tegakan Eucalyptus urograndis. Tekno Hutan Tanaman 3(1):13-22.

[34] Dariah, A., W. Hartatik, \& S. Rochayati. 2013. Sistem pengelolaan lahan sayuran yang bersifat 
lumintu. Prosiding Seminar Nasional Peningkatan

Produktivitas Sayuran Dataran Tinggi 7-20.

[35] Bokings, D.L., I.N. Sunarta, I.W. Narka, 2013.

Karakteristik terasering lahan sawah dan

pengelolaannya di Subak Jatiluwih, Kecamatan

Penebel, Kabupaten Tabanan. E-Jurnal

Agroekoteknologi Tropika 2(3): 175-183. 